\title{
Identification of Soil, Rock and Tecto-Volcanism on Landslides in Tondano Watershed
}

\author{
Muchtar S. Solle and Asmita Ahmad \\ Department of Soil Science Hasanuddin University, Jl. Perintis Kemerdekaan KM 10, Makassar 90245, Indonesia
}

\begin{abstract}
This research was aimed to identify the soil, rock, and tecto-volcanism in their association with landslides intensity in Tondano watershed. The methods were survey method (soil, rock, and geomorphology), joint data processing with stereonet 8 , X-ray diffractometers for clay mineral identification, and earthquake data processing with GIS 10.2 Software. The magnitude of earthquake was 4-5.4 mb that resulted from tecto-volcanism activity. The earthquake caused the instability of soil and rock, especially in fault zones. The rock has been strong deformed with the highly developed intensity of fractures (advanced stage). Soil dominated by Kaolinite and vermiculite minerals causes the instability conditions when it is saturated, while the nature of the bedrock with massive open fracture pattern causes the shear strength of the rocks decreases and on the contrary, the shear stress increases. Rainfall intensity is $73-145 \mathrm{~mm} /$ day that becomes a major factor of increased soil mass and burdening factor of the unstable rock. Slope is a factor that supports the intensity of mass movements of rock and soil in the form of shallow landslides.
\end{abstract}

Key words: Soil, rock, slope, rainfall, tecto-volcanism, shallow landslides.

\section{Introduction}

On January 15, 2014, landslides on the slopes of the hills along the Tondano River initiated the dammed flow of the river. On the same day, the natural levee collapsed leading to a destructive flash flood. As the result, 32 people were confirmed dead, 2 were missing, and 40,000 were evacuated [1].

Prior to the landslides and flash floods on January 15 , 2014, an earthquake of $4.1 \mathrm{mb}$ in magnitude occurred in Manado (Table 1). The earthquake has disrupted the stability of the soil and rocks. While the increased rain intensity a week before the disaster (Table 2) had triggered landslides in the area outside the outlet of Lake Tondano that filled up the river channels and slowed down the flow of water to downstream areas. High intensity rain upon the occurrence of disaster in almost all regions of the Manado Province, particularly the runoff flowing into the Tondano Lake, resulted to an over discharge of water to the outlets due to the shrinkage of the lake's surface area as the impact of

Corresponding author: Muchtar S. Solle, Dr., research fields: landslide and land degradation. land-use for agricultural areas, settlements and embankments. Runoff discharge over Lake Tondano increased the turbulent flow of river water and brought in the landslide's materials that had previously covered the river body. The downstream river areas endured the runoff in the form of flash flood that definitely caused both material and non-material loss.

The lithology is an important factor in the landslide due to its potential as a trigger factor and a huge impact to the landslide. Therefore, the mapping of areas prone to landslides as carried out by Refs. [2-4], entailed the parameters of lithology as the most important part in the study of landslides, since diverse units of lithology have different degrees of vulnerability to landslides [5-10]. Lithology has been accepted massively and significantly for the effect on the landslides. Furthermore, variations in lithology frequently lead to various strengths of slope and permeability of the rock and soil [3].

Several researches have conducted study on landslide and acknowledged that the parameters of slope and lithology are the main factors of landslides $[10,11]$ while the main triggers are rainfall and earthquakes. 
Table 1 The intensity of earthquake in Manado.

\begin{tabular}{llllllll}
\hline Time & Latitude & Longitude & Depth & Mag & Mag type & Place & Type \\
\hline 2014-01-30T20:06:04.940Z & 0.4023 & 125.5347 & 90.16 & 4.5 & $\mathrm{Mb}$ & $121 \mathrm{~km} \mathrm{SSE} \mathrm{of} \mathrm{Bitung,} \mathrm{Indonesia}$ & Earthquake \\
2014-01-25T05:41:35.960Z & 2.0018 & 124.6186 & 239.41 & 4.5 & $\mathrm{Mb}$ & $62 \mathrm{~km} \mathrm{NNW}$ of Manado, & Earthquake \\
2014-01-17T06:14:49.370Z & 2.542 & 125.8191 & 116.97 & 4 & $\mathrm{Mb}$ & $140 \mathrm{~km} \mathrm{NNE} \mathrm{of} \mathrm{Bitung,} \mathrm{Indonesia} \mathrm{Earthquake}$ \\
2014-01-03T05:12:54.040Z & 1.3488 & 125.8906 & 64.3 & 4.1 & $\mathrm{Mb}$ & $79 \mathrm{~km} \mathrm{E} \mathrm{of} \mathrm{Bitung,} \mathrm{Indonesia}$ & Earthquake \\
\hline
\end{tabular}

Source: BMKG, 2014.

Table 2 The daily rainfall in January 2014.

\begin{tabular}{|c|c|c|c|c|c|c|}
\hline Date & Station & Rainfall & Station & Rainfall & Station & Rainfall \\
\hline & & $\mathrm{mm}$ & & $\mathrm{mm}$ & & $\mathrm{mm}$ \\
\hline $1 / 1 / 2014$ & Bitung & 2.2 & Kayuwatu & 1 & Samratulangi & 0.6 \\
\hline $2 / 1 / 2014$ & & 13.5 & & 0 & & - \\
\hline $3 / 1 / 2014$ & & 6.2 & & - & & 8.1 \\
\hline $4 / 1 / 2014$ & & 0 & & 1.5 & & - \\
\hline $5 / 1 / 2014$ & & - & & 0.6 & & 2.4 \\
\hline $6 / 1 / 2014$ & & 0 & & - & & - \\
\hline $7 / 1 / 2014$ & & 13.4 & & 0.6 & & 5.8 \\
\hline $8 / 1 / 2014$ & & 28.8 & & 65.4 & & 43.1 \\
\hline $9 / 1 / 2014$ & & 12.9 & & 54.2 & & 64 \\
\hline $10 / 1 / 2014$ & & 0.5 & & 67.9 & & 78.2 \\
\hline $11 / 1 / 2014$ & & - & & 6.3 & & 6.1 \\
\hline $12 / 1 / 2014$ & & 2.6 & & 40.3 & & 43.8 \\
\hline $13 / 1 / 2014$ & & 10.9 & & 4.5 & & 10.6 \\
\hline $14 / 2 / 2014$ & & 0 & & 39 & & 0.2 \\
\hline $15 / 1 / 2015$ & & 73.3 & & 87.2 & & 145 \\
\hline $16 / 3 / 2014$ & & 41.2 & & 133.8 & & - \\
\hline $17 / 1 / 2016$ & & 0.2 & & 46.7 & & 16.5 \\
\hline $18 / 4 / 2014$ & & 0.7 & & 4.5 & & 5.6 \\
\hline $19 / 1 / 2017$ & & 2.5 & & 2 & & 2.6 \\
\hline $20 / 4 / 2015$ & & - & & 15 & & 19.1 \\
\hline $21 / 1 / 2018$ & & - & & 18.8 & & 5.4 \\
\hline $22 / 4 / 2016$ & & 3.2 & & 12 & & - \\
\hline $23 / 1 / 2019$ & & 0 & & 32 & & - \\
\hline $24 / 4 / 2017$ & & 7.7 & & 31.6 & & 4.4 \\
\hline $25 / 1 / 2020$ & & 10.9 & & & & 22.2 \\
\hline $26 / 4 / 2018$ & & 15.4 & & & & 42.9 \\
\hline $27 / 4 / 2019$ & & - & & 0.5 & & 1.2 \\
\hline $28 / 4 / 2020$ & & - & & - & & - \\
\hline $29 / 4 / 2021$ & & 0 & & - & & - \\
\hline $30 / 4 / 2022$ & & 0 & & 0.1 & & 0.9 \\
\hline
\end{tabular}

Description: Red indicated the increased rainfall intensity and Blue indicates the rainfall during the disaster (Source: BMKG, 2014).

However, study on the mineral content of rocks and soil as one determinant of the rock physical property on landslide vulnerability is very rare. Therefore, the purpose of this study was to analyze the mineral content of rocks and soil in Tondano watershed and its relationship with tecto-volcanism on shallow landslide that frequently occurs in Tondano watershed.

\section{Research Methods}

The methods used in this study were the analyses of 
surface geology, namely: (1) Lithology included analysis of the physical appearance of rocks, minerals, and rock layers; (2) Structural Geology included analysis of seismic data, gas leakage from volcanism, joint and structural symptoms of the landform morphological appearance; (3) Geomorphology included the physical characteristics of watershed, landform, river morphology, river flow patterns, and stadia area.

Tools and materials used in this study were the ARL Quant X (EDXRF Analyzer) for XRF and Shimadzu XRD-7000 for XRD, map of the region geology (scale of 1: 250,000), RBI map (scale of 1: 50,000), seismic data (BMKG of 2014), GIS 10.2 software, and geological compass and hammer, GPS, and Stereonet 8 software.

\section{Results and Discussion}

Indisputably, natural disasters are highly associated with the environmental factors, particularly the land utilization and the allocation. Unsuitable allocation of objects regarding with an area carrying capacity will result on land degradation and landslides. Therefore, it is very important to analyze the carrying capacity of Tondano watershed in North Sulawesi. There were several central aspects of the study, one of them was the aspects of geology consisting of the aspects of geomorphology, lithology/formations, soil mineralogy, and geological structure.

\section{Geomorphology}

The development of geomorphology of Tondano North Sulawesi is inseparable from the processes of Resen active tectonics and volcanic and Plio-Pleistocene ancient tectonics [12, 13]. Resen climate activities with rainfall ranged from 2,000 $\mathrm{mm} / \mathrm{yr}->4,000 \mathrm{~mm} / \mathrm{yr}$, also became an external factor in shaping the current landform. Based on Desaunettes' classification [14], the geomorphology (landform) of Tondano watershed can be divided into three, namely: (1) Alluvial landform (A), (2) Volcanic landform (V), and (3) Structural landform (T). In conjunction with the landslides, the volcanic and structural landform will be explicated briefly.

Volcanic Landform (V): Landform was formed from the volcanic activity within the Plio-Pleistocene to Resen period. Ancient volcanic activity is characterized by the formation of ancient caldera lake, which is Tondano Lake. Basaltic lava flow with a slope of $\mathrm{N} 1^{\circ} \mathrm{E} / 16$ at the position of $\mathrm{N}^{\circ} 24^{\prime} 23.70^{\prime \prime}$ and $124^{\circ}$ 52 ' 19.30", and the emergence of hot spots are the evidence of seepage magma (Fig. 1). Active volcanic activities trigger shallow volcanic earthquakes that adversely affect the rocks' stability at steep slopes and consequently, lead to soil and rock slides.

Structural Landform (T): Plio-Pleistocene tectonic activity caused the uplift that occurred on the east side of Tondano watershed and formed structural mountains. Tectonic processes also constructed strike slip fault in the northern part of the study site and formed structural hills and mountains, with a slope of $20-30 \%$ (Fig. 2). According to Ref. [11], slope becomes a very essential factor in the occurrence of landslides. Vulnerability zonation is considerably related to the slope. The slope of $>15^{\circ}$ requires serious alert to the possibility of landslides surely by considering other supporting factors.

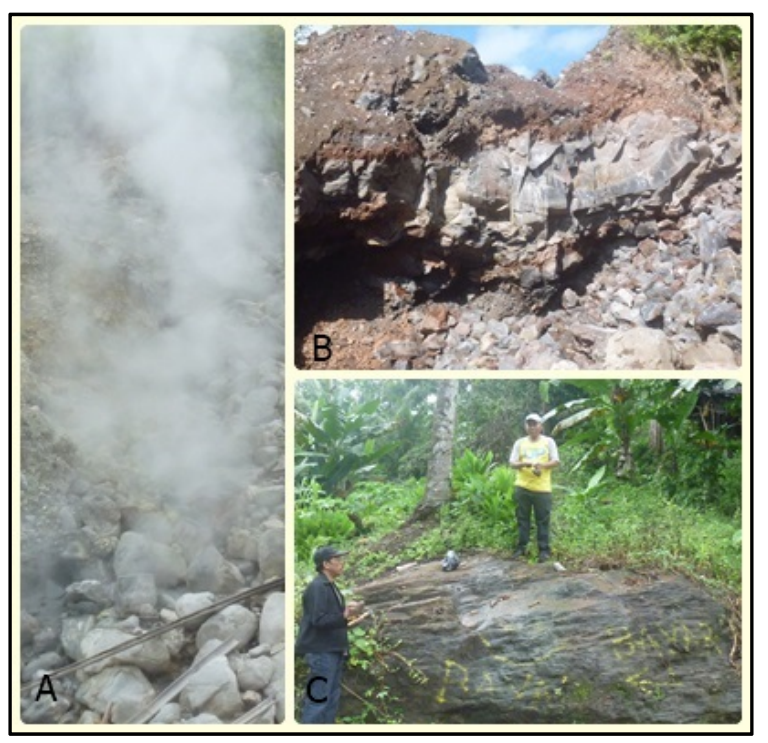

Fig. 1 The appearance of jets of gas (A), and basaltic lava flows (B and C). 


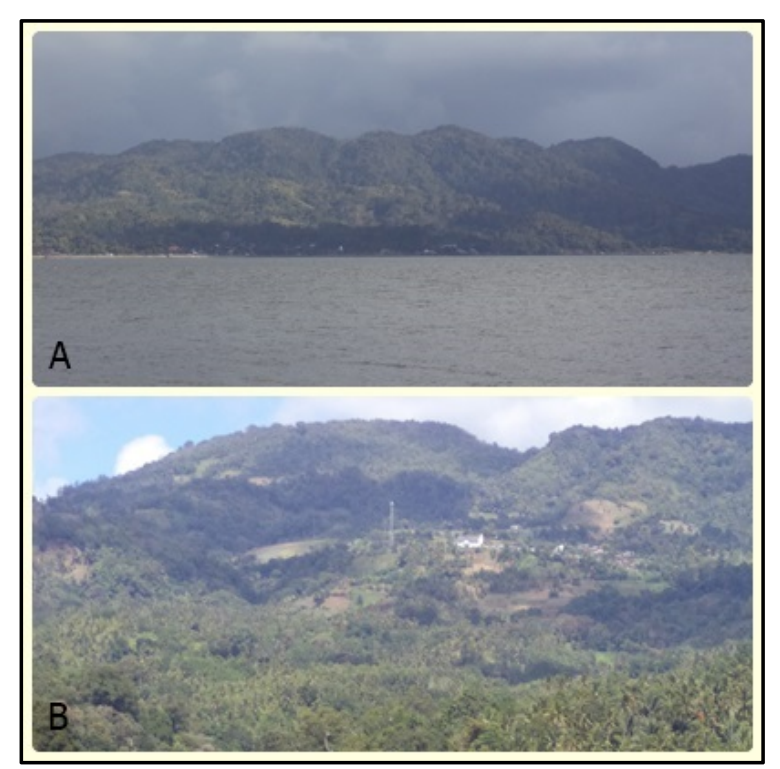

Fig. 2 The appearance of the structural mountains (A) at the eastern part of Tondano Lake, and the appearance of the structural hills and mountains in the northern part of Tondano watershed (B).

\section{Lithology}

The lithology of Tondano watershed used in the study of landslide referred to the Geological Sheet of Manado [15]. In addition, the lithology constituent is derived from five formations: (1) Alluvium Quarter (Qa), (2) Lakes and Rivers Quarter (Qs), (3) Volcanic Quarter (Qv), (4) Volcanic Tondano Quarter (Qvt) and (5) Volcanic Miocene Tertiary Quarter (Tmv).

Qa (Alluvium Quarter): consists of boulders, gravels, pebbles, and mud, found in the northern part of Tondano watershed and occupies $2 \%$ of the research site.

Qs (Lake and River Quarter): consists of sand, silt, and conglomerate, and marly clay, found at the center of Tondano watershed and occupies approximately $10 \%$ of the research site. Depositions are spread around Tondano Lake located in the plateau area and utilized as paddy fields (Fig. 3).

Qv (Volcanic Quarter): consists of young volcanic rocks; lava, bombs, lapilli and volcanic ash; forming young stratovolcanoes, one of them located in the research site, which is the Lokon Mountain. Lava released by Lokon Mountain is constituted mainly from basalt (Fig. 4). The quarter is at the western part of the research site distributed from the north to the south and occupies approximately $35 \%$ of the research site. Lava at the research site, in general, is in a condition of strongly jointed and some are ruptured (Fig. 5). Nevertheless, it is a direct impact of intense seismic activity taking place in the research site, both volcanic and tectonic earthquakes. Earthquake has lowered the shear strength of rocks and increased the shear stress. Area which constituted of Qv formation should be gained serious concern in its development since mass movement simply occurs in most of the source rocks.

Qtv and Qtvl (Volcanic Tondano Quarter and Lava Volcanic Tondano Quarter): consist of coarse clastic sedimentary rocks especially composed of andesitic,

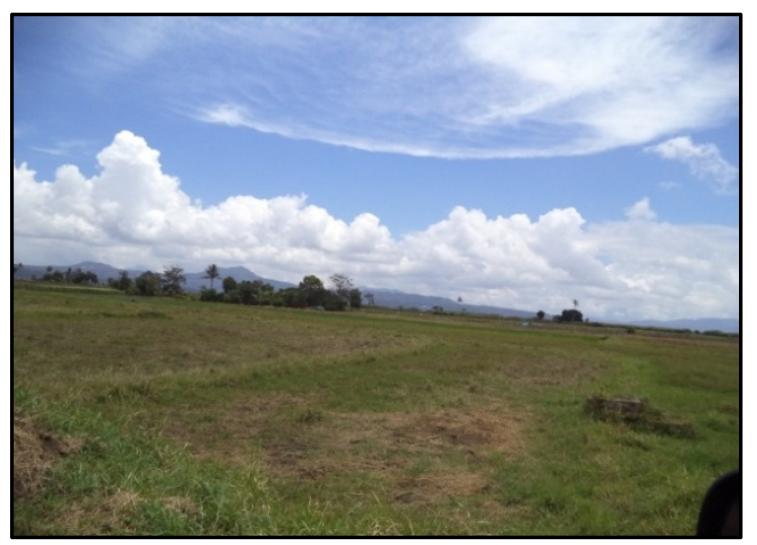

Fig. 3 The appearance of sediment unit of Qs formation, which is utilized as paddy fields.

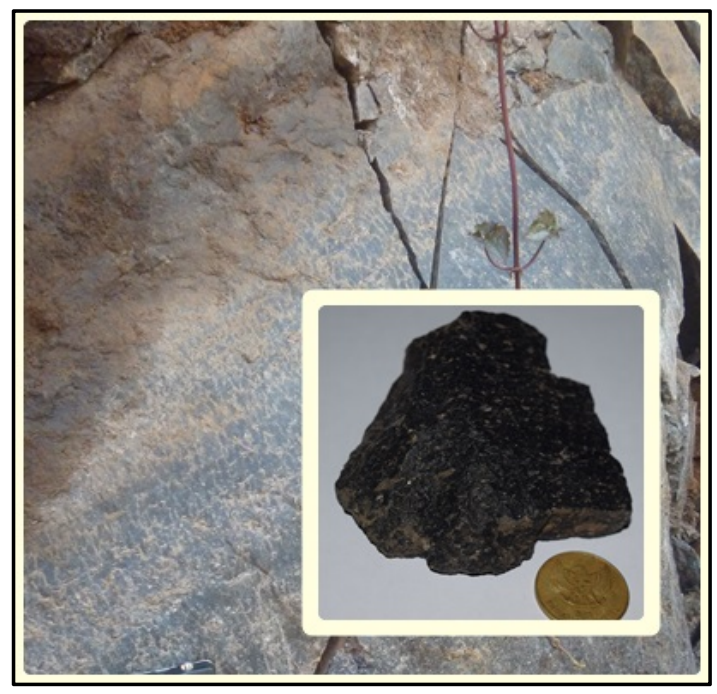

Fig. 4 The appearance of igneous basalt unit of Qv formation. 


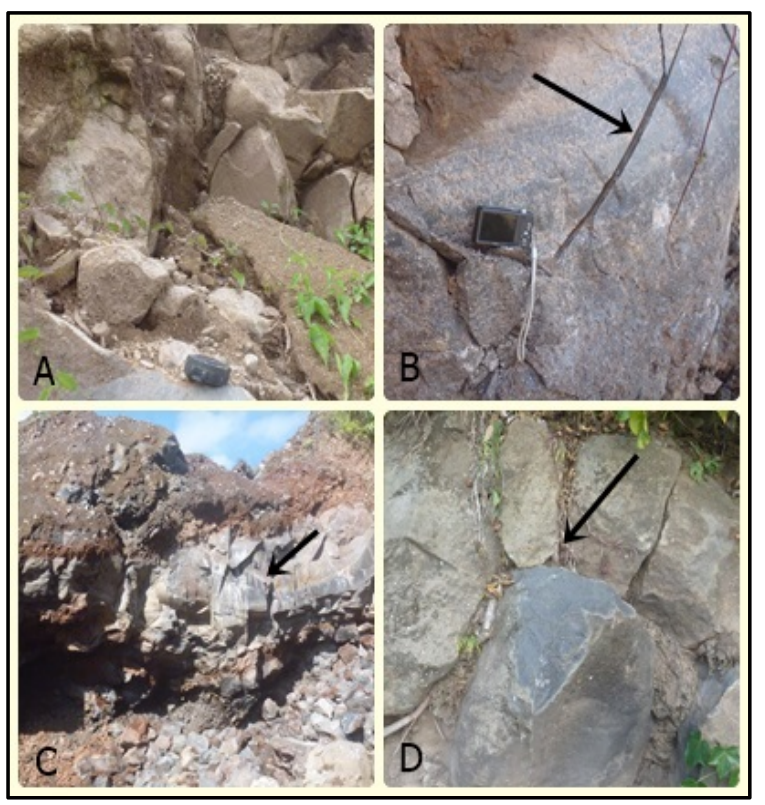

Fig. 5 Igneous basalt unit of Qv formation undergoes strong joint leading to destruction.

constituted of the angled to moderate angled components, characterized by numerous pieces of pumice; lapilli pumice, breccias, high solid overlies, structured flow (Fig. 6). The units are located in the area adjacent to Tondano Lake in the northern part of Minahasa; forming a low wavy ridge. Pyroclastics deposition is allegedly to originate from and occurred as a result of a vast eruption in the formation of Tondano Caldera. Formation is exposed in the local section of the north and south of the research site and occupies $28 \%$ of the research site. High rainfall (ranges between $2,000-3,000 \mathrm{~mm} / \mathrm{yr}$ and total rainy days between 90-139 days) contributed to the soil formation in which Qtv Formation reached 3 meters in thickness (Fig. 6).

Rainfall intensity with instable rocks due to the tecto-volcanism process, in addition to steep slope are the roots of the rock mass prone to a movement.

Tmv (Volcanic Miocene Tertiary): consists of volcanic rocks; mainly constituted of breccias, lavas, and tuffs. Lava flows are generally constituted of andesite to basalt. Very coarse grained breccias composed of andesite (Fig. 7), partly conglomerate, with tuff, sandstone, and claystone content. The formation found at the western part of the research site

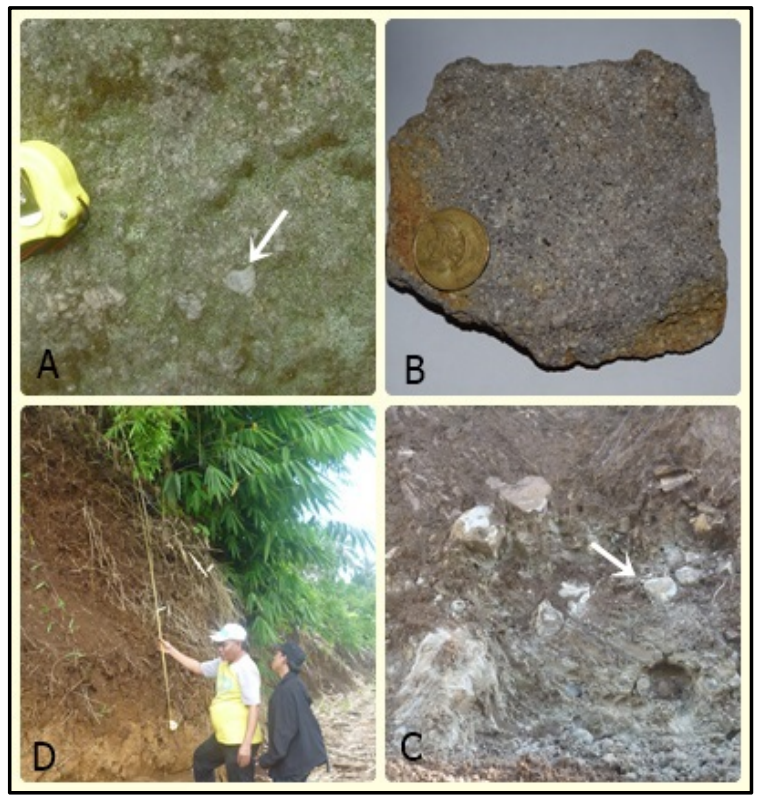

Fig. 6 The appearance of breccias volcanic unit of Qtv formation (A), with andesitic fragments (B). High rainfall intensity accelerates the weathering $(C)$ that leads to easy defragmentation (white arrow). The formation of soil solum reaches a thickness of 3 meters (D).

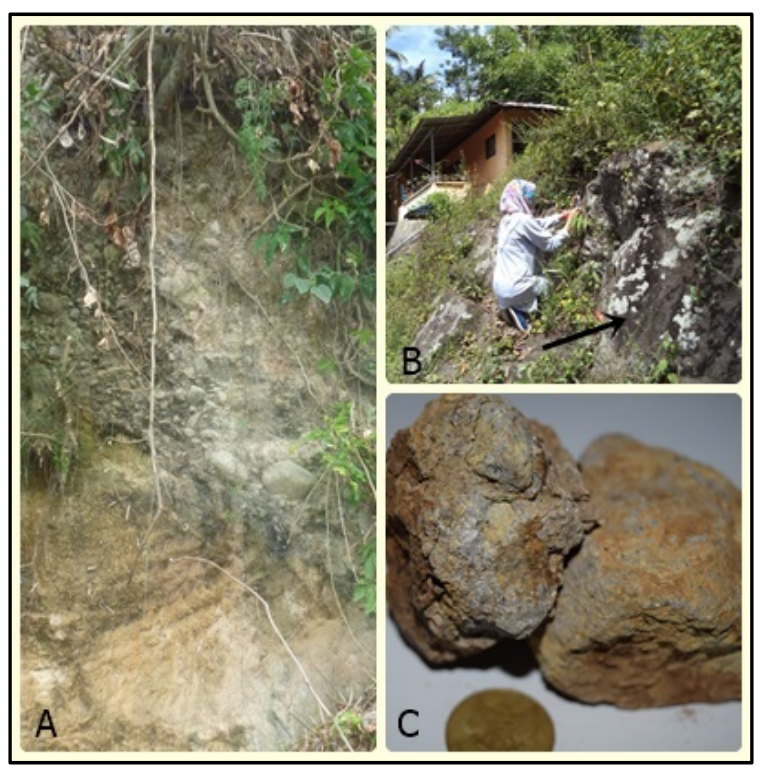

Fig. 7 The appearance of breccias (A) of the Tmv formation, with the components of andesitic fragments (C). (B): The appearance of the andesite lava unit of Tmv formation (black arrow).

spread from the west and occupied $15 \%$ of the research site.

Rock mass has undergone a process of early tectonism, thus, it becomes more massive and the weathering process is slower. However, the source 
rocks triggered by the activity of Resen tecto-volcanism can endure the movement through the previous ruptures. The movement will be intensified if it is supported by topography and steep slopes.

\section{Mineralogy of Soils and Rocks}

The results of mineralogical analysis of a number of samples in the sites indicated that the type of clay mineral content of $1: 1$ is more dominant than clay type $2: 1$ and clay type $2: 2$. The content of clay minerals can reduce the stability of the slope in a saturated condition [16,17]. Clay mineral type $1: 1$ of Kaolinite type tends to swelling, while the Halloysite type tends to be limited swelling, and type 2:1 of Vermiculite type also has a propensity to be limited swelling. The three types of mineral in saturated conditions can enhance the weight of the soil mass that will burden the parent rock underneath and trigger landslides.

Several points of the site indicated of fairly Kaolinite mineral content up to $43 \%$ of total clay content (Fig. 8). In Kali village and Kembes village, Vermiculite and Halloysite mineral contents are higher than Kaolinite mineral content. Nevertheless, it is potential to set off the higher intensity of the landslide than other villages. It is mainly due to the capacities of Vermiculite and Halloysite mineral to absorb water which are higher Kaolinite mineral (Fig. 9), thus, it will add the soil mass in saturated condition.

Result of XRF test for Resen pyroclastic materials demonstrated two distinct characteristics of silica content (Fig. 10). High silica component is layered between the layers of soil and low silica component. High silica component is loosened if the water content in the soil is in saturated condition.

Source rocks that come from pyroclastic material with sufficiently high silica content coupled with soil masses that can limit swelling and water saturated resulting in high potential intensity of land and rocks slides occurrences in Tondano watershed, North Sulawesi.

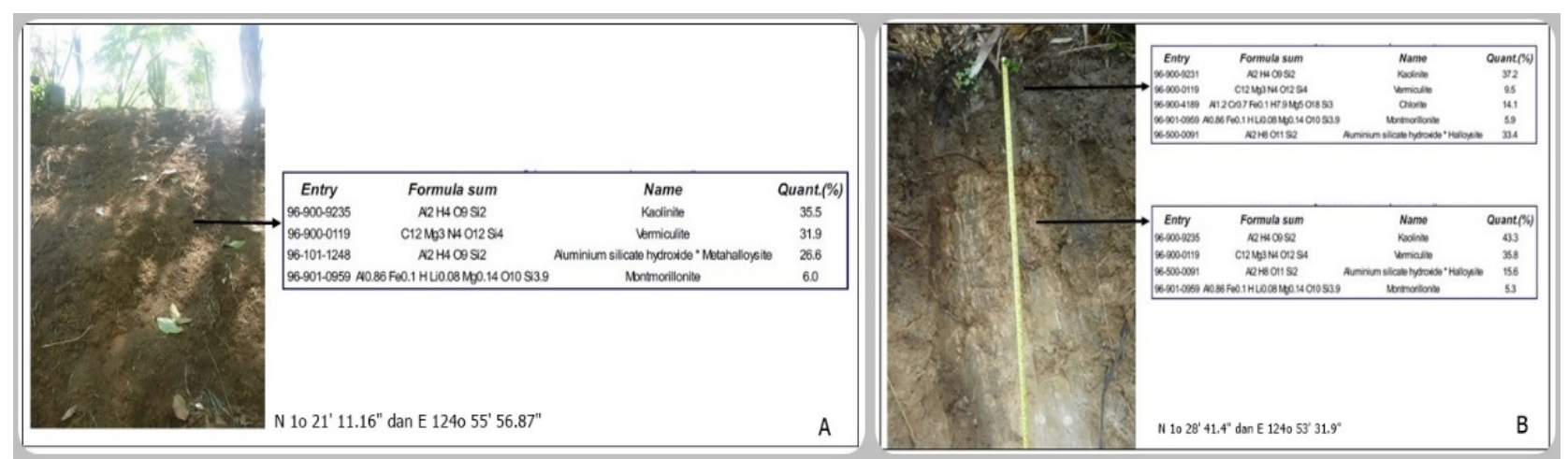

Fig. 8 Kaolinite mineral content reaches $43 \%$.

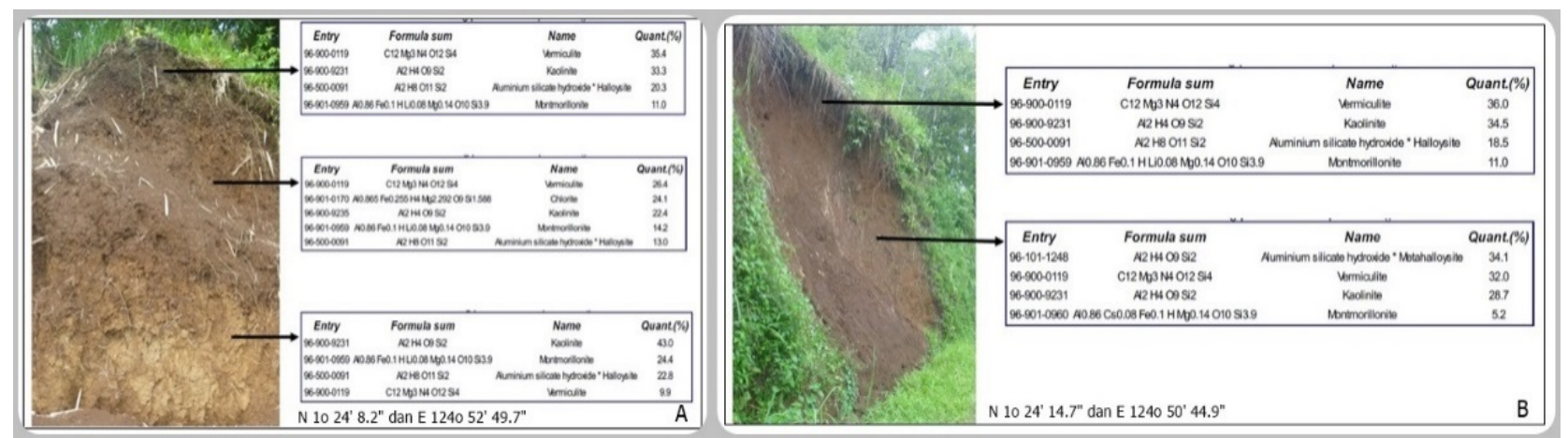

Fig. 9 Vermiculite and Halloysite mineral content are higher than Kaolinite content, the potential of landslides increased 2-fold. 


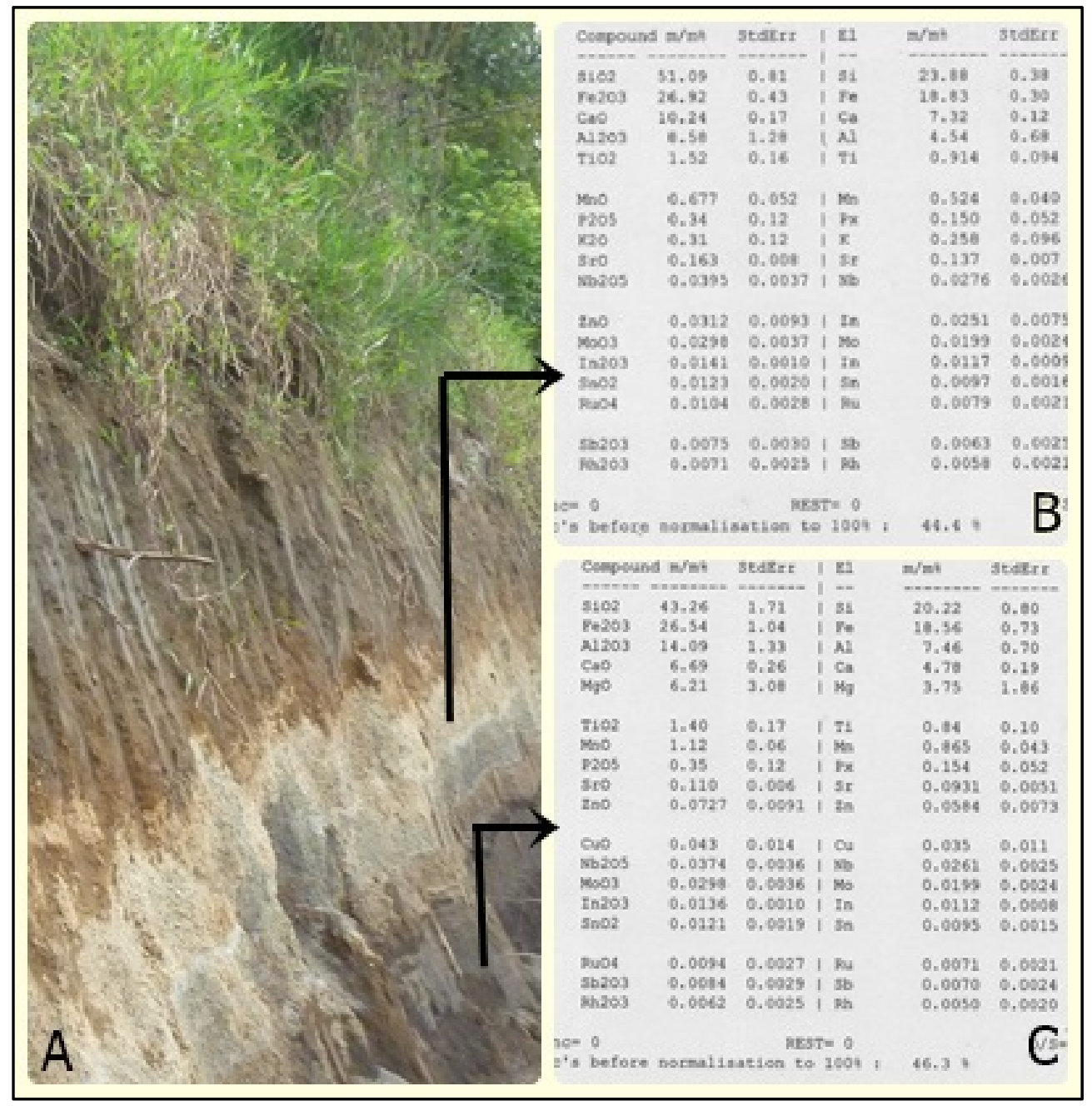

Fig. 10 Soil morphology with the source materials of incoherent pyroclastic material (A). There are two types of pyroclastic material, e.g., andesitic (B) and basaltic (C).

\subsection{Structural Geology}

Geological evolution of Minahasa is closely related with control factors of the structure of volcanic arc basin late Tertiary-Quaternary North Sulawesi and Sangihe [18]. The area has experienced the recurrence phase of eruption and active tectonics, which can be identified by the formation of pull-apart basin. It continued with the development of volcanism in the area marked by the establishment of Tondano Caldera at $2+0.4$ j.t.l. $[13,19]$, which developed into the Tondano Lake as it is today.

In fact, the seismic intensity of volcanism and tectonism persists and has a very significant effect on the occurrence of disasters in Tondano watershed.

\subsection{Earthquake}

Along the year, the areas in Manado Province endure seismic activity both earthquakes centered on land and under the ocean (Fig. 11). Frequently, they are seismic activities with the magnitude of 4 to $4.5 \mathrm{mb}$ [20]. Vibrations generated from these activities lead to declined stability of rock and soil and trigger the movement as well as the landslide.

\subsection{Joint}

Joint found in the research site is the direct impact of seismic activity, both of the current or the Tertiary activities. Most of lithology has been fractured in several orders of joint, but merely some of them can be 


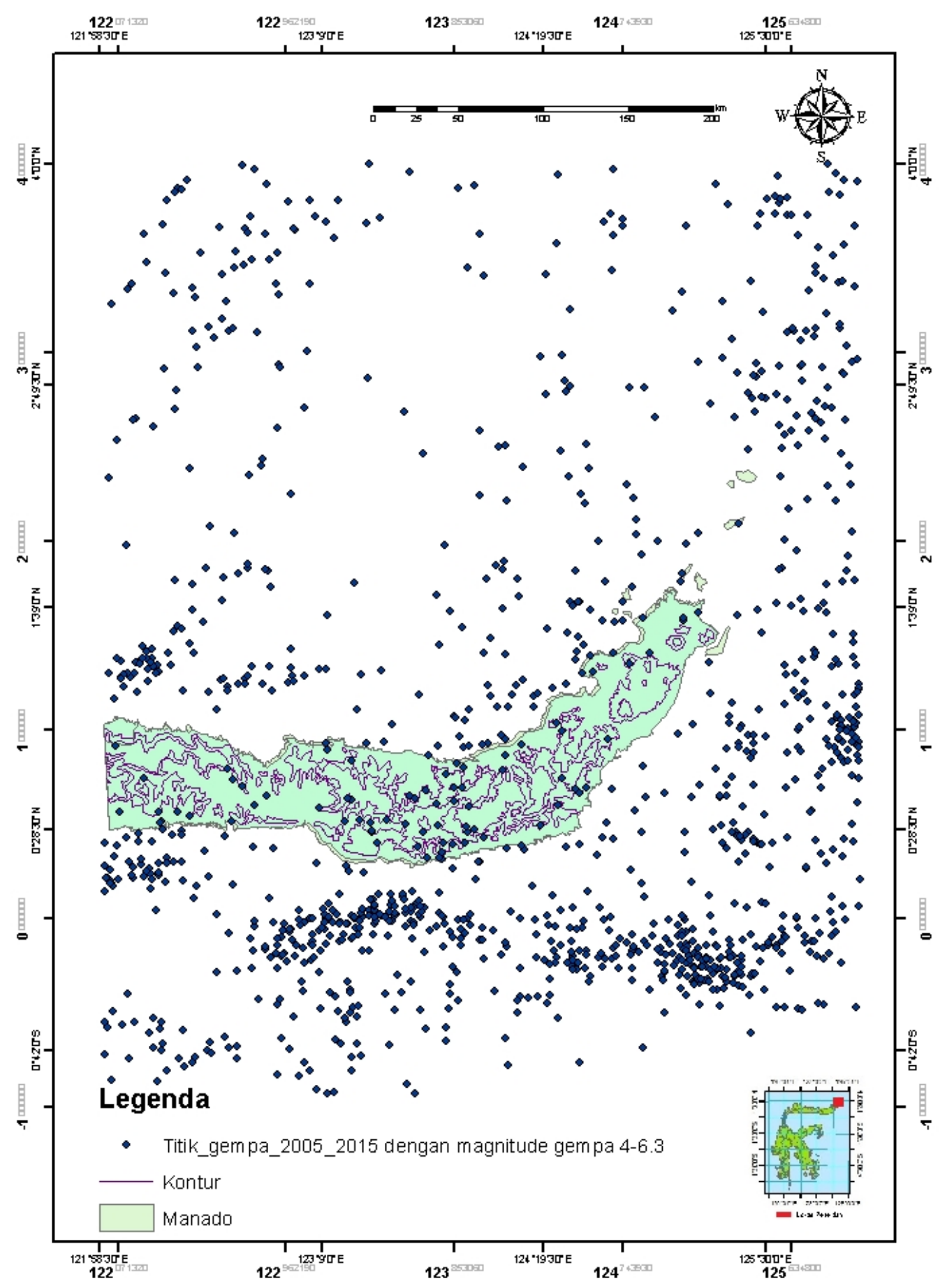

Fig. 11 Seismicity map of North Sulawesi which affects the stability of the soil and rocks in Tondano watershed. 


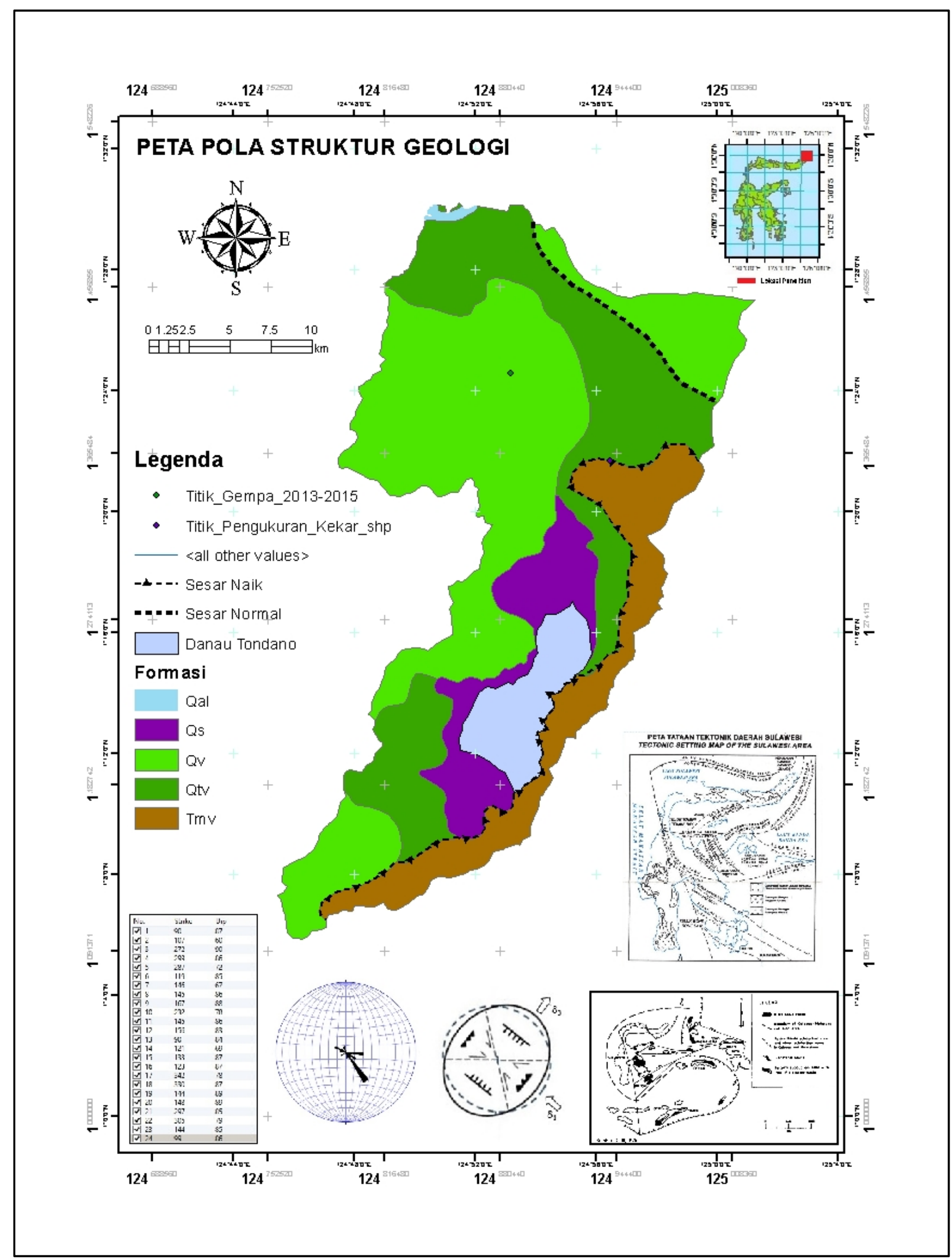

Fig. 12 The pattern of structural geology formed the fault in Tondano watershed. Accumulation of joint data in a rosette diagram showed the main straightness direction of NW-SE as indicated by $\delta 1$ pattern [24]. It is in line with the regional tectonic map $[12,15]$. 


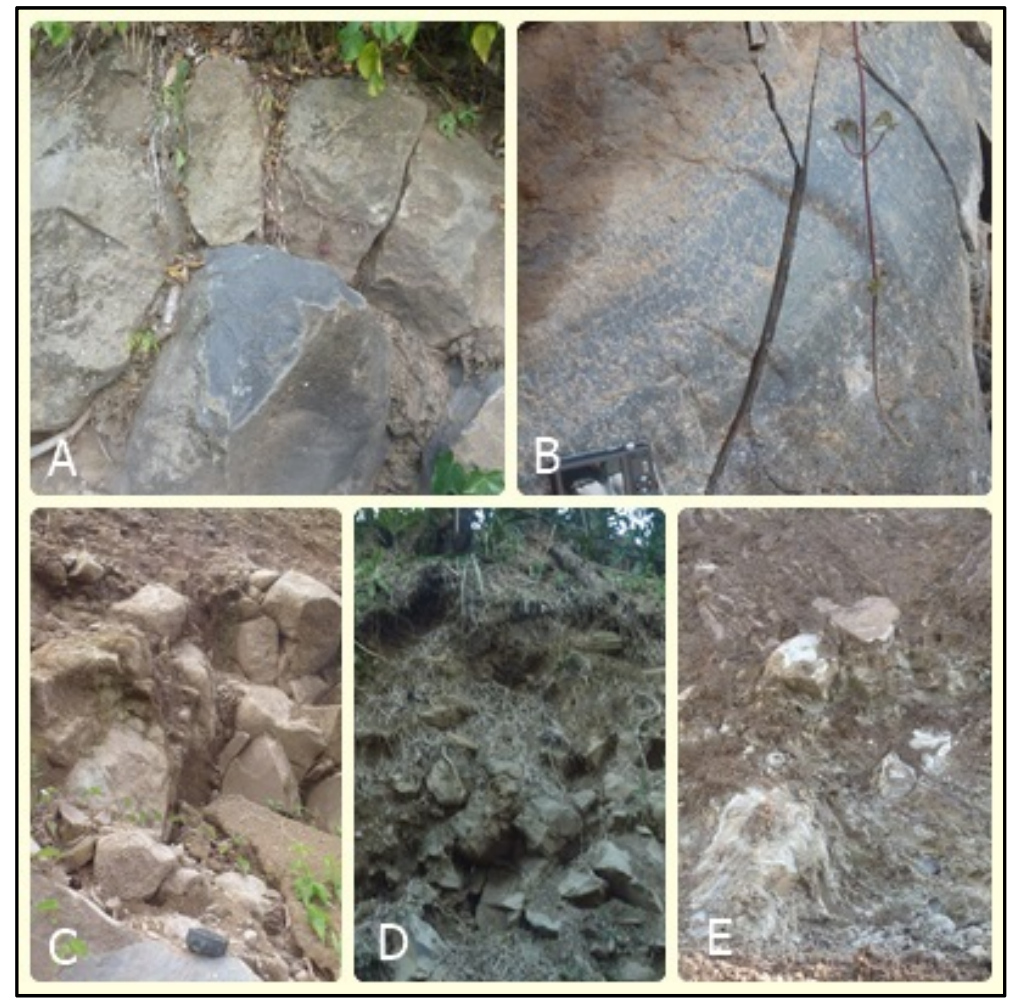

Fig. 13 The condition of lithology that has endured increased shear stress and declined shear strength. (A) The area adjacent to Tondano Lake, Eris district, (B) the area adjacent to Lokon Mountain, Tomohon, (C) Tinoor, (D) Eris district, (E) Air Madidi, East Tondano district.

measured directly in the site, particularly due to: (1) The volcanic activity has covered most of the objects in the site; (2) Joints occurred on pyroclastic rocks are hardly recognized and identified as the result of their fragmented and matrix physical characteristics which make the joint straightness hardly identified.

The results of joint measurement on the unit of andesitic lava of Tmv Formation of TMV, showed the data of the main sharpness direction $(\sigma 1)$ with relative trend of NW-SE (northwest-southeast) (Fig. 12). It is similar with the direction of the regional rock block of Sulawesi with a trend of NW-SE [21-23].

\subsection{Fault}

According to Ref. [12], the process of active tectonism after the formation of Sulawesi Island was commenced in Plio-Pleistocene, with the formation of fault uplift on on NE-SW direction in the northern part of Sulawesi, which lifted up the old rocks of Tmv formation to the top of Qv and Qtv. The impact of the fault uplift was the stretching at the northeast part of the fault uplift that led to the formation of horst (the raised fault block bounded by normal faults or graben) of Qtv Formation above Qv Formation (Fig. 12).

The results of the ancient tectonism had influenced the rock structure through the fractures of rock, either of major or minor scale. The fractures of the fault process became increasingly unstable due to the intensity of the circum-Pacific seismic through North Sulawesi. It activated the volcanic activity that exacerbated the stability of the rock through volcanic earthquakes and volcanic eruptions process, eventually, leading to the increased shear stress and declined shear strength of the rocks in Tondano watershed (Fig. 13), in addition to avalanche in several parts.

\section{Conclusions}

(1) The occurrence of an earthquake with a magnitude of 4-4.5 mb in Bitung Manado and the increased intensity of rainfall within week in prior to 
the disastrous flash flood approximately $145 \mathrm{~mm} /$ day. The vibrations caused by volcanic and tectonic earthquake activity lead to declined stability of rock and soil, which makes them vulnerable to movement and landslide;

(2) Direction of the main tectonic sharpness $(\sigma 1)$ is with relative trend of NW-SE;

(3) Soil contains higher Vermiculite and Halloysite in comparison with Kaolinite minerals. It triggers the increased intensity of the landslide in the form of shallow landslides.

\section{Acknowledgement}

The authors would like to express their gratitude to the Directorate of Higher Education (DIKTI) and Lembaga Penelitian dan Pengabdian Masyarakat (LP2M) Hasanuddin University for the research grant, thus, the entire activities of study could be accomplished.

\section{References}

[1] BNPB. 2014. "Data dan Informasi Bencana Indonesia." http://dibi.bnpb.go.id/. Accessed May 2015.

[2] Dai, F. C., and Lee, C. F. 2002. "Landslide Characteristics and Slope Instability Modeling Using GIS, Lantau Island, Hongkong." Geomorp Journal 42: 213-28.

[3] Ayalew, L., and Yamagishi, H. 2005. "The Application of GIS-Based Logistic for Landslide Susceptibility Mapping I the Kakuda-Yahiko Mountains, Central Japan." Geomorphology Journal 65: 15-31.

[4] Yalcin, A. 2008. "GIS-Based Landslide Susceptibility Mapping Using Analytical Hierarchy Process and Bivariate Statistics in Anderson (Turkey): Comparision of Results and Confirmations." Catena 1: 1-12.

[5] Dai, F. C., Lee, C. F., and Ngai, Y. Y. 2001. "Landslide Risk Assessment and Management: An Overview." Journal of Engineering Geol 64: 65-87.

[6] Yesilnacar, E., and Topal, T. 2005. "Landslide Susceptibility Mapping: A Comparison of Logistic Regression and Neural Networks Methods in a Medium Scale Study, Hendek Region (Turkey).” Eng Geol 79 (3-4): 251-66.

[7] Yalcin, A., and Bulut, F. 2007. "Landslide Susceptibility Mapping Using GIS and Digital Photogrammetric Techniques: A Case Study from Ardesen (NE-Turkey).” Nat. Hazards 41: 201-26.

[8] Garcia-Rodriguez, M. J., Malpica, J. A., Benito, B., and
Diaz, M. 2008. "Susceptibility Assessment of Earthquake-Triggered Landslides in El Salvador Using Logistic Regression." Journal Geomorphology 95: 172-91.

[9] Nefeslioglu, H. A., Gokkceoglu, C., and Sonmez, H. 2008. "An Assessment on the Use Logistic Regression and Artificial Neural Networks." Engineering Geol. Journal 97: 171-98.

[10] Solle, M. S., Paharuddin, Ahmad, A., and Ansar, dan M. 2014. "Landslides Zonation at the Budong-budong Watershed, Central Mamuju District of West Sulawesi Province." Forum Geografi 28 (2): 119-26.

[11] Karnawati, D. 2001. "Bencana Alam Gerakan Tanah Indonesia Tahun 2000 (Evaluasidan Rekomendasi).” Jurusan Teknik Geologi. Fakultas Teknik Universitas Gadjah Mada. Yogyakarta.

[12] Katili, J. A. 1975. "Volcanism and Plate Tectonics in the Indonesian Island Arcs." Tectonophysics Journal 26: 165-88.

[13] Lécuyer, K., Bellier, O., Gourgaud, A., and dan Vincent, P. M. 1997. "Active Tectonics of North-East Sulawesi (Indonesia) and Structural Control of the Tondano Caldera." C. R. Acad. Sci. Paris, Earth Planet. Sci. 325: 607-13.

[14] Desaunettes, J. P. 1977. "Catalogue of Landforms for Indonesia." Prepared for the Land Capability Appraisal Project at the Soil Research Institute. Bogor, Indonesia.

[15] Effendi, A. C., and Bawono, dan S. S. 1996. "Peta Geologi Regional Manado 1:250.000.” Pusat Penelitiandan Pengembangan Geologi. Bandung, Indonesia.

[16] Yalcin, A. 2007. "Environmental Impacts of Landslides: A Case Study from East Black Sea Region, Turkey." Environmental Engineering Science 24 (6): 821-33.

[17] Baoping, W., and Haiyang, C. 2007. "Mineral Compositions and Elements Concentration as Indicators for the Role of Groundwater in the Development of Landslides Slip Zones; a Case Study of Large-Scale Landslides in the Three Gorges Area in China." Earth Sciences Frontiers 14 (6): 98-106.

[18] Moechtar, H., Pratomo, I., and Mulyana, H. 2007. "Gerakanstrukturdankaitannyadenganfaktorkendalitekton ik, berdasarkananalisisstartigrafi; studikasusgeologikuarterterhadapfaseperkembangan Danau Tondanopurbasepanjang Remboken-Kakas, Kec. Rembokendan Kec. Kakas, Kab. Tomohon, Sulawesi Utara.” Jurnal Geologi Indonesia 2 (3): 177-90.

[19] Pratomo, I., and danLecuyer, F. 2007. "Sebaran GunungapiKuarter di Minahasa (Sulawesi Utara), dalamkonteks volcano-tektonik. Jurnal Sumberdaya Geologi, Dalampersiapanpenerbitan (inprep).”

[20] BMKG.

2014. 
http://www.bmkg.go.id/BMKG_Pusat/default.bmkg. Accessed April 16, 2015.

[21] Siahaan, E. E., Soemarinda, S., Fauzi, A., Silitonga, T., Azimudin, T., and Raharjo, I. B. 2005. "Tectonism and Volcanism Study in the Minahasa Compartment of the North Arm of Sulawesi Related to Lahendong Geothermal Field, Indonesia." In Proceedings World Geothermal Congress, 24-9.

[22] Calvert, S. J., and Hall, R. 2007. "Cenozoic Evolution of the Lariang and Karama Regions, Basin, Western Sulawesi, Indonesia.” Journal Petroleum Geosciences 13:
353-68.

[23] Hall, R. 2012. "Late Jurassic-Cenozoic Reconstructions of the Indonesian Region and the Indian Ocean.” Journal Tectonophysics 570-571: 1-41.

[24] Davis, G. H., and Reynolds, S. J. 1996. Structural Geology of Rocks and Regions. 2nd edition. New York: John Wiley and Sons Inc., 776.

[25] Priyono, Kuswaji, 2008. "Analisismorfometridanmorfostrukturlerengkejadianlong sor di Kecamatan Banjarmangu Kabupaten Banjarnegara." Forum Geografi 22 (1): 53-69. 